\title{
How Can Restaurant Business Manage Promotional Mix in Facing Society 5,0?
}

\author{
Gayatri Atmadi \\ Department of Communication Science, Faculty of Social \& Political Science \\ University of Al Azhar Indonesia \\ \{gayatriuai@gmail.com\}
}

\begin{abstract}
Digital transformation has changed many aspects of people's lives, such as health, education, finance, tourism, and restaurants business. This research aims to get an analysis description of how The Duck King restaurant in Jakarta facing increasingly fierce business competition in digital era. To communicate with public effectively and maintain loyal costumers of the restaurant, the owner of restaurant as marketer has to consider several factors in developing the promotional mix programs those involve audience contacts, namely : public relations, sales promotions, advertising, digital promotion, events and sponsorships. This case study research uses mixed method methodology, namely : qualitative research and quantitative research. On qualitative research method, data collected by being participant-observer, indepth interviewing with four informants and collecting online databases. On quantitative research method, data collected by doing content analysis from instagram account of the Duck King restaurant (\#theduckkingid) and unit analysis of the research is pictures and words. The principal results of the research indicate that The Duck King restaurant can create the network society where the owner as marketer can settle many social challenges by integrating some innovations in facing society 5.0. By utilizing very important data from database marketing, the company can enhance interactions with customers and develop customer loyalty.
\end{abstract}

Keywords: Customer Relationship Management; Integrated Marketing Communication; Promotional Mix; Restaurant Business

\section{Introduction}

Fierce competition in the restaurant business in Indonesia is increasingly interesting to analyze. Eating in a restaurant can be a family recreation now in the midst of the routine of a big city community in Indonesia. Not surprisingly, the restaurant industry, especially for fine dining restaurants in big cities is growing rapidly because people's demand for healthy, clean, and delicious food needs is increasing. According to Nicole Przybylski [1], "as the bigest market for the Food Service Industry in ASEAN region, Indonesia is expected to show a compounded annual growth rate (CAGR) between 2018 and 2023 of $7.06 \%$ ". 
Generally speaking, the most common types of restaurants are fine dining restaurant, casul dining, fast food, and café. The focus of this research is fine dining restaurant in Jakarta, Indonesia with the brand The Duck King restaurant. According to Rozekhi et al. [2], researcher from Penang, the food quality accredits in fine dining restaurants are expected to be important and simultaneously could satisfy diners with the quality of its core value, such as healthy and freshness, menu collection, visual presentation of food, temperature, and tasteful.

As a famous fine dining restaurant in Jakarta, The Duck King restaurant faces very intense competition among many fine dining restaurants in Indonesia. Moreover, many restaurants develop their website and social media for supporting business activities, some of them use delivery orders facility to make easy for someone to order food and drink in any places and any time. For this time being, on digital integrated marketing communication perspective, The Duck King restaurant develops its website (the ducking.com), instagram : theduckkingid, facebook : The Duck King Group and twitter : @ TheDuckKingID so many people can get information about the company, menu, news, promotions, and locations.

In facing society 5.0 as era of enjoying life, the fine dining restaurant business like The Duck King needs to pay attention seriously for integrated marketing communication on Internet of Things practices that bring profits to the company. Based on the explanation above, this research seeks to : (1). Provide a comprehensive explanation about integrated marketing communication activities of The Duck King restaurant Jakarta; (2). Compile the classification of messages that become representation of marketing communication activities from instagram theduckkingid.

Generally speaking, the company needs customer relationship management (CRM) for maintaning communication with customers both new and old customers and also to improve service and customer loyalty to the company. In digital era with Internet of Things thinking, the company can build and develop CRM with social media, such as facebook, instagram, youtube, and twitter. Networking by social media is now important aspect of every day life. "Kenneth E.Clow and Donald Baack" [3] explained that personal touch for customer can build long-term loyalty and customer engagement with the use of digital media. Effective programs of customer relationship management are organized to make a good tactics for mass communication and products.

In digital era, people's media habits have changed. Many people rely less on television, radio and newspapers and more on internet by using their handphone for searching the newest information on their hand anytime and anyplace. In effect, the companies and organizations must adapt with the new digital technology and provide integrated marketing communication solutions. Keith J. Tuckwell [4] explained that unified of marketing communications program commits organization of all forms of marketing communications in integrated program that raises the impact on customers as target market. It grasps some elements, such as advertising, special events, interactive communication with digital media, public relations, sales promotion, personal selling, and sponsorship. According to "Kenneth E. Clow and Donald Baack" [5], "to build loyalty, many marketing efforts have been made to engage customers with the brand at every contact point".

Promotion is a vital element in the marketing communication program, especially for relation with consumers purchasing decisions. According to Belch and Belch [6], there are six elements in promotional mix, such as : advertising, direct marketing, digital marketing, sales promotion, personal selling, and public relations. This current research will focus for analyzing three elements of promotional mix, namely : advertising, public relations, and sales promotion since they are published on instagram \# theduckkingid. "Kenneth E. Clow and Donald Baack" [7] also explained that "advertising continues to be a major component of 
unified of marketing communications. The role advertising plays varies by company, product, and the firm's marketing goals".

Public Relations Society of America", 2012 [8] stated that "Public Relations is a strategic communication process that develops mutually favorable relationships between company and their publics". On the other hand, Belch and Belch [9] explained about "Sales Promotion which is generally defined as those marketing activities that provide extra value or incentives to the sales force, the distributors, or the ultimate consumer and can stimulate immediate sales". Jamil Abdulkarim Abdullah [10] argued that "promotional mix elements are the major communication mix tools being used by approximately all of the marketers to positively impact consumers purchasing decision. His study concluded that there is a positive relationship between promotional mix elements and purchasing decision. Advertising achieved the highest positive correlation".

\section{Method}

This case study uses mixed methods research with sequential exploratory model. Firstly, the study uses the qualitative research methodology by interviewing four informants as members of Farmers Market at Mall Kelapa Gading 1, North Jakarta who attended Cooking Class with the Cheff from The Duck King Restaurant on March 2, 2019. Informants are required to answer some questions from researcher on July 27, 2019 and most of them are 50 years old and over. Based on the initial survey, most of the participants of Cooking Class in Farmers Market Kelapa Gading are 50 years old and over. Cooking Class is a weekly program at Farmers Market in Jakarta for its loyality consumers. Afterthat, the study uses the quantitative research methodology by doing content analysis from instagram account of the Duck King restaurant (theduckkingid). Unit analysis of this research is pictures and words. During the research period from March 1, 2019 to May 31, 2019, there were 120 pictures posting on instagram.

\section{Result and Discussion}

PT. Jaya Bersama Indo with the brand of The Duck King Restaurant (TDR) opened for the first time in 2003 in South Jakarta. "At the moment, TDR have assumed as the biggest chain of chinese restaurants in Indonesia that operated 32 branches under 5 different segments; namely, The Grand Duck King Signature as the signature concept, The Grand Duck King as typical concept, The Duck King as the core concept, Imperial Chef as non halal food based restaurant concept, and The Duck King Noodle and Kitchen as the simple concept which specialize in Lamian menu"[11].

To collect the real data from the consumers and instagram account, this study conduct in two ways of the research. First of all, collecting data by interviewing four informants as a participants at Cooking Class with the Cheff from The Duck King Restaurants (TDR). Those informants are woman with 50 years old and over. The reason of choosing 4 informants cause they are the loyal consumers in Farmers Market Mall Kelapa Gading and also consumers at The Duck King restaurants. Farmers Market Mall Kelapa Gading and The Duck King restaurant already made joint cooperation for developing Cooking Class in super market since two years ago. Afterthat, collecting data by doing content analysis from instagram account : theduckkingid. from March 1, 2019 to May 31, 2019. 


\subsection{Informants' Perceptions on Integrated Marketing Communication}

From the interview of four informants who attend and learn how to cook several recipes from The Duck King Restaurant on March 2, 2019 at Farmers Market, Mal Kelapa Gading at 11.00-13.00, this study explains that Cooking Class event is the way of TDR public relations to engage with its stakeholders, especially with loyal customers from Farmers Market. In other words, the company already developed their integrated marketing communication programs that consits of public relations, sales promotion and advertising. The company also handled customer relationship management by making join cooperation with Farmers Market that already had big data about the loyal customer who had Trust card member. From that big data, The Duck King invited the members of Farmers Market to join with Cooking Class with the Cheff from the restaurant.

Based on interview with some informants has revealed that WhatsAp is the best media promotion for Cooking Class of The Duck King Restaurant. In fact, there was no promotion information about Cooking Class on March 2, 2019 that published on instagram. Informants as consumers at Farmers Market Kelapa Gading and The Duck King restaurants get information about Cooking Class from their friends and WhatsAp group that consists of loyal consumers who often did shopping in Farmers Market. This finding argues that social media, such as instagram as the symbol of IR 4.0 can not be regarded as the most vital for communicating with the community of Cooking Class group. The most interesting finding of this research that human relations is the most important thing among social media.

This finding confirms Adelina Eugenia Ivanov [12] who said that "online marketing communications should not be regarded as the most important and the only way to communicate the organization's messages". "It requires coordinated approach in terms of marketing communications, with particular emphasis on elements such as understanding consumer needs and behavior, use databases customers, integrated media and communiccation with stakeholders."

\subsection{E-Promotional Mix Elements using Instagram}

For three months of research time, there are 120 pictures posting in instagram theduckkingid. From the content analysis of instagram account, some interesting findings were revealed as explained on some tables, such as :

Table 1. E-Promotional Mix Elements on \#theduckkingid

\begin{tabular}{lccl}
\hline No. & $\begin{array}{c}\text { E-Promotional } \\
\text { Mix Elements }\end{array}$ & $\begin{array}{c}\text { Number } \\
\text { of Posts }\end{array}$ & \multicolumn{1}{c}{ Analysis } \\
\hline 1. & Public Relations & 15 & $\begin{array}{l}\text { It consists information about some special religious day and } \\
\text { invitation cooking class for the kids. Moreover, it contains } \\
\text { information about celebrating national consumer day with } \\
\text { special prices. }\end{array}$ \\
2. Sales Promotion & 39 & $\begin{array}{l}\text { It contains information about cashback gift voucher for live } \\
\text { seafood menu, special discount for credit card holders and } \\
\text { debit card holders } \\
\text { It consists of information about all-you-can-eat dimsum promo, } \\
\text { lunch and dinner promo, promotion of e-Cash voucher, the } \\
\text { modern vegetarian menu and break-fasting together }\end{array}$ \\
\hline
\end{tabular}


The above table indicates that advertising element (55\%) is the biggest amount among others while sales promotion element (32,5\%), and public relations element (12,5\%). Many of the advertising information talk about lunch and dinner promotion with e-Cash voucher while sales promotion information is about cashback gift vouchers and special discounts for kredit card holders. On public relations perspective, the restaurants already gave aprreciation and attention to their stakeholders, such as loyal consumers with ACI card, kids, Islam consumers, Christian consumers and Hindu consumers. It indicates that restaurant maintained good relations with their all customers for good image and reputation as the fine-dining restaurant in Jakarta. By analyzing dialog at instagram, sometimes dissapointed consumers gave critics cause ACI card can't be usefull for them.

So in facing industrial revolution 4.0 and society 5.0, The Duck King restaurant already created the network society by making a loyalty program where the company can enhance interactions with customers and develop customer loyalty, namely ACI card. This finding confirms the explanation from Resendes[13] explained that "sometimes guests might need a little nudge to choose your restaurant over a nearby competitor, and that's where a digitally integrated loyalty program can help". "A loyalty program that integrates with handphone is better for every one." Based on the data of sales promotion activities show that the restaurants already had joint relations with some banks in Indonesia for special discounts. As one of favourit menu, the restaurant also gave special prices for dimsum with many kinds of taste. Moreover, the restaurant is very active in giving persuasive information about their promo of products and services as its advertising activities, sometimes twice or three times a day, consumers get information about The Duck King resto from instagram. However, the company did not make publication about Cooking Class on March 2, 2019 at Farmers Market Kelapa Gading. It meant that the administrator of the instagram of theduckkingid could not make the promotion about cooking class accuratly and properly. Fortunately, most of the participants of the cooking class used WhatsAp group for communicating each other better.

Douglas M. Lambert [14] explained "the objective of CRM at the strategic level is to identify markets and target segments, provide criteria for segmenting customers, provide customer teams with guidelines for customizing the product and service offering, develop a framework for metrics, and provide guidelines for the sharing of process improvement benefits with the customers." From this point of view, The Duck King already identify market and target segments properly by inviting the loyal customers of Farmers Market to attend the Cooking Class as special event for the public relations activities. Generally speaking, the target market of The Duck King restaurant is middle up class as the same as the target segment of Farmers Market is middle up class too. Another research from Mohita Maggon and Harish Chaudhry [15] explained that "managing customer relationships is a demanding task as the customers' needs keep on changing gradually." Therefore, The Duck King should manage customer relations better by improving the newest information as the content of instagram although not all of the informants used instagram. Only some of them used instagram as their social media.

\section{Conclusions}

The result of the research argues that social media, such as instagram as the symbol of IR 4.0 can not be regarded as the most vital for communicating with any community. The most interesting finding of this research reveal that communication based on human relations is the most important thing than social media. Actually, the role of instagram as social media just as 
the supplement of the real communication with others. So the restaurant business should think seriously with regard to the programs of integrated marketing communications with particular emphasis on promotional mix for understanding consumer buying behaviour by using databases customers and integrated communication with its stakeholders. Implication of this research, in facing society 5.0, other restaurant business can adopt the public relations way of The Duck King restaurant developed the Cooking Class as a good event to make consumers engagement based on big data and internet of thing via whatsAp so that it can make people's lives more comfortable, happy and safe.

\section{References}

[1] N. Przybylski. Outlook on the Food Service Industry in Indonesia, Retrieved from https://www.indonesia-investments.com/business/business-columns/outlook-onthe-food-service-industry-in-indonesia/item9001), 2018.

[2] N.A. Rozekhi,,S. Hussin,Ashraf Siddik Khan Abd Rahim Siddiqe, Putri-Dahlia Ab Rashid, and Noor Saliza Salmi. The Influence of Food Quality on Customer Satisfaction in Fine Dining Restaurant : Case in Penang. International Academic Research Journal of Business \& Technology 2(2),pg 45-50, 2016.

[3] K.E. Clow, D. Baack. Integrated Advertising, Promotion, and Marketing Communications, Sixth Edition. USA : Pearson, 2014.

[4] Tuckwell, Keith J. Integrated Marketing Communications Strategic Planning Perspectives, Second Edition. Toronto : Pearson Prentice Hall, 2008.

[5] K.E. Clow, D. Baack. Integrated Advertising, Promotion, and Marketing Communications, Sixth Edition. USA : Pearson, 2014.

[6] G.E.Belch,M.A. Belch, MA. Advertising and Promotion. Global Edition, Singapore : Mc.Graw Hill Education, 2015

[7] K.E. Clow, D. Baack. Integrated Advertising, Promotion, and Marketing Communications, Sixth Edition. USA : Pearson, 2014.

[8] Public relations defined : A Modern definition for the new era of public relations, Retrieved from https://www.prsa.org/about/all-about-pr, 2012.

[9] G.E.Belch, M.A. Belch, MA. Advertising and Promotion. Global Edition, Singapore : Mc.Graw Hill Education, 2015

[10] J.A. Abdullah. "The Impact of Promotional Mix Elements on Consumers Purchasing Decisions”. Journal for Studies in Management \& Planning. e-ISSN:2395-0463 Vol. 02 Issue 1.2016.

[11] theduckking.com/about/The Duck King Story. Date of access : April 25,2019.

[12] A.E. Ivanov. " The internet's impact on Integrated Marketing Communication." Procedia Economics and Finance, No. 3. Pp. 536-542, 2012.

[13] S. Resendes. Growing Your Business with Restaurant Data Analytics. Retrieved from https://upserve.com/restaurant-insider/restaurant-data-analytics/, 2019.

[14] D.M. Lambert. "Customer Relationship Management As A Business Process.” Journal of Business \& Industrial Marketing, Vol.s'sepi25, No.1, pp. 4-17, 2010.

[15] M. Maggon, H. Chaudhry. "Exploring Relationships Between Customer Satisfaction and Customer Attitude from Customer Relationship Management Viewpoint: An Empirical Study of Leisure Travellers". FIIB Business Review Vol.7, No.1, pp. 57-65, 2018. 